\title{
Validation of tissue microarray technology in ovarian carcinoma
}

\author{
Daniel G Rosen ${ }^{1}$, Xuelin Huang ${ }^{2}$, Michael T Deavers ${ }^{1}$, Anais Malpica ${ }^{1}$, Elvio G Silva ${ }^{1}$ and \\ Jinsong Liu ${ }^{1}$ \\ ${ }^{1}$ Department of Pathology and ${ }^{2}$ Department of Biostatistics, The University of Texas MD Anderson Cancer \\ Center, Houston, TX, USA
}

\begin{abstract}
High-throughput tissue microarray allows many clinical specimens to be analyzed simultaneously on a single slide. One potential limitation of tissue microarray is the correct representation of each tumor with the small tissue core. Because tumors from different organs have different levels of heterogeneity, it requires a validation study for each one of them. We compared immunostaining of Ki-67, estrogen receptors, and p53 in whole sections of 45 cases of high-grade serous ovarian carcinoma with six core samples from those sections with regard to the number of tissue cores needed to reliably represent a whole section. Staining for Ki-67 was graded high or low by automated image analysis of 10 high-power fields; staining for estrogen receptor and p53 was scored on a 0-to-3 scale. Correlation coefficients for whole-section vs core stains were 0.86 for $\mathrm{Ki}-67,0.93$ for estrogen receptors, and 0.82 for p53. A total of $54(6.6 \%)$ of the cores were inadequate for scoring. The probability that results from one core would correctly represent all three markers in the whole section was $91 \%$; that for two cores was $96 \%$; and that for three cores was $98 \%$. Our results show that analysis of a single readable core matched the staining pattern of a whole section more than $90 \%$ of the time, and analysis of two cores increased that value to more than $95 \%$, demonstrating that ovarian carcinoma tissue microarray is a reliable technique to analyze the expression of markers.

Modern Pathology (2004) 17, 790-797, advance online publication, 9 April 2004; doi:10.1038/modpathol.3800120
\end{abstract}

Keywords: ovarian carcinoma; tissue microarrays; validation; immunohistochemistry; Ki-67; estrogen receptors; p53

The introduction of tissue microarray technology by Kononen et al in $1998^{1}$ has greatly facilitated the retrospective study of large sets of formalin-fixed, paraffin-embedded tissues. With this high-throughput technology, hundreds of samples can be arrayed in a single paraffin block that can then be analyzed with a variety of techniques, including immunohistochemical analysis and fluorescence in situ hybridization. In contrast to traditional methods, which require processing hundreds of slides, tissue microarray technology allows large numbers of specimens to be processed under identical conditions, which greatly reduces the time, cost and amount of archival tissue required for analysis. Tissue banks linked to comprehensive clinical databases, procured through patient consent and protected by stringent ethical criteria, will be one of the most

Correspondence: Dr J Liu, MD, PhD, Department of Pathology, Unit 85, The University of Texas MD Anderson Cancer Center, 1515 Holcombe Blvd, Houston, TX 77030-4095, USA.

E-mail: jliu@mdanderson.org.

Received 18 December 2003; revised and accepted 4 February 2004; published online 9 April 2004 crucial resources for discovering and validating various potential biomarkers. One of the potential disadvantages of tissue microarray analysis is that a single small core may not accurately represent the entire tumor. Several previous studies in breast carcinoma demonstrate that the analysis of two or three cores provides a good tumor representation. ${ }^{2}$ Whether such small tissue cores can adequately represent the patterns of whole sections in highly heterogeneous tumors such as human ovarian cancer remains unclear. We addressed this issue by comparing immunohistochemical staining for the proliferation marker $\mathrm{Ki}-67$, the estrogen receptor (ER), and p53 between whole sections of specimens of high-grade serous ovarian carcinoma and tissue cores obtained from those sections and arranged in a tissue microarray.

\section{Materials and methods}

Formalin-fixed, paraffin-embedded tissue blocks from 45 consecutive cases from 1990 to 1994 of high-grade serous carcinoma of the ovary were selected. The tissue blocks had been stored under 
ambient conditions at approximately $24^{\circ} \mathrm{C}$. Four sections were removed from each block: one for each of the three markers to be tested (Ki-67, ER, and p53) and one for hematoxylin- and- eosin (H\&E) staining before the tissue microarray blocks were created. The H\&E-stained sections were reviewed by a pathologist to identify representative areas of tumor from which to acquire the cores for microarray analysis. Histological diagnosis was based on the Gynecologic Oncology Group criteria. ${ }^{3}$ Tissue microarray blocks were constructed by taking six core samples from the identified areas of paraffinembedded tumor tissues and assembling those cores on a recipient paraffin block. Creation of the blocks was done with a precision instrument (Beecher Instruments, Silver Spring, MD, USA) that uses two separate core needles for punching the donor and recipient blocks and a micrometer-precise coordinate system for assembling the microsamples on a block (Figure 1a). For each case, six $1 \mathrm{~mm}$ in diameter and 0.4-mm in depth cores, were collected and placed in the same recipient block. The final tissue microarray consisted of two blocks, one containing 150 spots (Block 1) and the other 120 spots (Block 2), with samples spaced $0.5 \mathrm{~mm}$ apart (Figure 1b). Sections ( $5 \mu \mathrm{m})$ were obtained from each block and stained with H\&E to confirm the presence

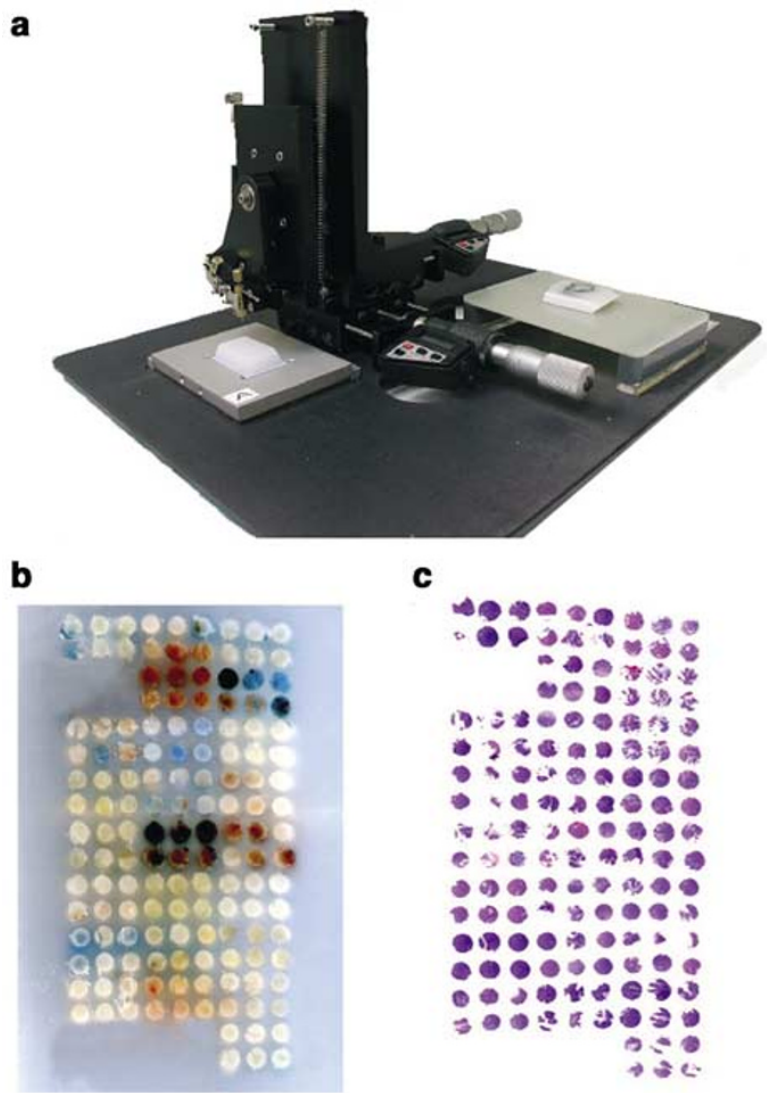

Figure 1 (a) Tissue microarrayer device. (b) Overview of tissue microarray block. (c) Overview of H\&E-stained tissue microarray slide. of tumor and to assess tumor histology (Figure 1c). Three consecutive sections from each tissue microarray block were subjected to immunostaining (Figure 2).

Sample tracking was based on coordinate positions for each tissue spot in the tissue microarray block; the spots were transferred onto tissue microarray slides for staining. The sample tracking system was linked to a Microsoft Excel 2000 spreadsheet (version 9.0). The array was read according to the given tissue microarray map; each core was scored individually and the results were entered into the spreadsheet. All 45 cases showed at least two readable cores, considered necessary to be included in the study. Findings from whole sections were scored separately, and those scores were entered into the spreadsheet as well.

\section{Immunohistochemical Analysis}

The tissue microarray slides were subjected to immunohistochemical staining as follows. After initial deparaffinization, endogenous peroxidase activity was blocked with $0.3 \%$ hydrogen peroxide. Deparaffinized sections were microwaved in $10 \mathrm{mM}$ citrate buffer ( $\mathrm{pH}$ 6.0) to unmask the epitopes. The slides were then incubated with monoclonal antibodies against p53 (DAKO clone DO-7 in a 1:100 dilution for $60 \mathrm{~min}$ at room temperature); Ki-67 (DAKO, in a 1:100 dilution for $60 \mathrm{~min}$ at room temperature); or ER (Novocastra, in a 1:50 dilution for $60 \mathrm{~min}$ at room temperature). This was followed by incubation with biotin-labeled secondary antibody (DAKO EnVision) for $30 \mathrm{~min}$ and then with a 1:40 solution of streptavidin:peroxidase for $30 \mathrm{~min}$. Slides were then stained for 8 min with $0.05 \% 3^{\prime}, 3-$ diaminobenzidine tetrahydrochloride and then counterstained with hematoxylin, dehydrated, and mounted. Colon carcinoma, normal endometrium and normal lymph node were used as a positive control for p53, estrogen receptors and Ki-67, respectively. Negative controls were made by replacing the primary antibody with phosphate-buffered saline. All controls gave satisfactory results. At least $10 \%$ of the core had to contain tumor to be scored.

The immunostained slides were reviewed by a pathologist (DR), who followed the tissue microarray map to record a score for each sample. That reviewer was blinded to all sample identifiers; any scoring discrepancies among cores and between cores and whole section were resolved by a second pathologist (JL). Ki-67 staining was graded by automated image analysis (Nikon Eclipse TE 2000U with Meta Vue System software, Meta Series version 6.1 ); an index value of more than $15 \%$ was considered high, and an index value of $15 \%$ or less was considered low. ${ }^{4}$ Staining for p53 and ER was graded as follows: 0 , negative (no cells stained); 1 , weakly positive ( $<10 \%$ of cells stained); 2 , moderately positive $(10-50 \%$ of cells stained); or 3 , strongly positive ( $>50 \%$ cells stained). ${ }^{5}$ 

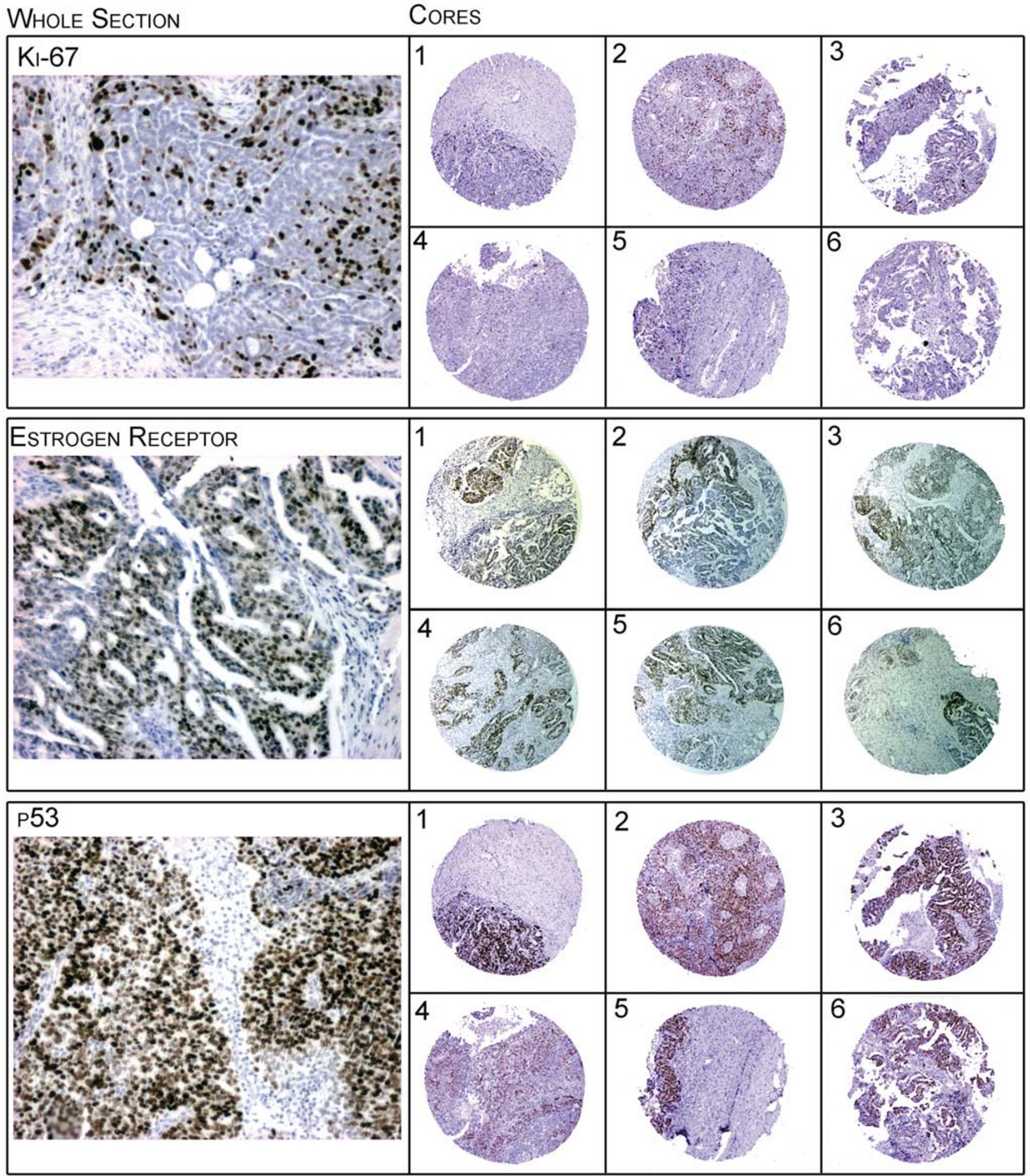

Figure 2 Staining for p53, Ki67, and ER of the whole sections $(\times 20)$ were compared with that of the cores $(\times 4)$

\section{Statistical Analysis}

We assessed the validity of the tissue microarray technique in terms of the percentage of cores in which the findings matched those of the corresponding whole section. A positive grade of a core and a positive score of a whole section (or a score of 'high' for Ki-67) was considered a match, regardless of grade number $(1,2$, or 3 ). A negative grade (ie, a grade of 0 ) matched a negative grade or a 'low' Ki-67 score. Cores that were lost during processing and 
Table 1 Summary of cases analyzed

\begin{tabular}{|c|c|c|c|c|c|c|c|c|c|c|c|c|c|c|c|}
\hline \multirow{4}{*}{$\begin{array}{l}\text { Case } \\
\text { no. }\end{array}$} & \multicolumn{15}{|c|}{ Markers analyzed } \\
\hline & \multicolumn{5}{|c|}{ Ki-67 } & \multicolumn{5}{|c|}{ Estrogen receptor } & \multicolumn{5}{|c|}{ p53 } \\
\hline & \multicolumn{2}{|c|}{$\begin{array}{l}\text { Grade in whole } \\
\text { section }\end{array}$} & \multicolumn{3}{|c|}{ No. of cores } & \multicolumn{2}{|c|}{$\begin{array}{l}\text { Grade in whole } \\
\text { section }\end{array}$} & \multicolumn{3}{|c|}{ No. of cores } & \multicolumn{2}{|c|}{$\begin{array}{l}\text { Grade in whole } \\
\text { section }\end{array}$} & \multicolumn{2}{|c|}{ No. of cores } & \\
\hline & & Pos & Neg & $\begin{array}{l}\text { No } \\
\text { tumor }\end{array}$ & $\begin{array}{l}\text { Lost } \\
\text { core }\end{array}$ & & Pos & Neg & $\begin{array}{c}\text { No } \\
\text { tumor }\end{array}$ & $\begin{array}{l}\text { Lost } \\
\text { core }\end{array}$ & & Pos & Neg & $\begin{array}{c}\text { No } \\
\text { tumor }\end{array}$ & $\begin{array}{l}\text { Lost } \\
\text { core }\end{array}$ \\
\hline 1 & $\mathrm{H}$ & 4 & 0 & 2 & 0 & 3 & 6 & 0 & 0 & 0 & 3 & 2 & 2 & 2 & 0 \\
\hline 2 & $\mathrm{H}$ & 6 & 0 & 0 & 0 & 0 & 0 & 6 & 0 & 0 & 3 & 6 & 0 & 0 & 0 \\
\hline 3 & $\mathrm{~L}$ & 0 & 6 & 0 & 0 & 3 & 6 & 0 & 0 & 0 & 0 & 0 & 6 & 0 & 0 \\
\hline 4 & $\mathrm{H}$ & 6 & 0 & 0 & 0 & 0 & 0 & 6 & 0 & 0 & 0 & 0 & 6 & 0 & 0 \\
\hline 5 & $\mathrm{~L}$ & 0 & 6 & 0 & 0 & 1 & 6 & 0 & 0 & 0 & 2 & 5 & 0 & 0 & 1 \\
\hline 6 & $\mathrm{H}$ & 6 & 0 & 0 & 0 & 1 & 6 & 0 & 0 & 0 & 3 & 6 & 0 & 0 & 0 \\
\hline 7 & $\mathrm{H}$ & 6 & 0 & 0 & 0 & 1 & 6 & 0 & 0 & 0 & 2 & 6 & 0 & 0 & 0 \\
\hline 8 & $\mathrm{H}$ & 6 & 0 & 0 & 0 & 1 & 5 & 0 & 0 & 1 & 2 & 5 & 0 & 0 & 1 \\
\hline 9 & $\mathrm{~L}$ & 0 & 6 & 0 & 0 & 2 & 6 & 0 & 0 & 0 & 0 & 0 & 6 & 0 & 0 \\
\hline 10 & $\mathrm{H}$ & 5 & 0 & 1 & 0 & 0 & 0 & 3 & 0 & 3 & 2 & 3 & 0 & 0 & 3 \\
\hline 11 & $\mathrm{H}$ & 6 & 0 & 0 & 0 & 1 & 6 & 0 & 0 & 0 & 3 & 6 & 0 & 0 & 0 \\
\hline 12 & $\mathrm{H}$ & 6 & 0 & 0 & 0 & 1 & 6 & 0 & 0 & 0 & 0 & 0 & 6 & 0 & 0 \\
\hline 13 & $\mathrm{~L}$ & 0 & 6 & 0 & 0 & 2 & 5 & 0 & 1 & 0 & 2 & 5 & 0 & 1 & 0 \\
\hline 14 & $\mathrm{H}$ & 6 & 0 & 0 & 0 & 1 & 5 & 1 & 0 & 0 & 0 & 0 & 6 & 0 & 0 \\
\hline 15 & $\mathrm{~L}$ & 0 & 6 & 0 & 0 & 3 & 6 & 0 & 0 & 0 & 0 & 0 & 6 & 0 & 0 \\
\hline 16 & $\mathrm{H}$ & 4 & 0 & 0 & 2 & 2 & 6 & 0 & 0 & 0 & 2 & 6 & 0 & 0 & 0 \\
\hline 17 & $\mathrm{H}$ & 5 & 0 & 1 & 0 & 0 & 0 & 6 & 0 & 0 & 0 & 0 & 5 & 1 & 0 \\
\hline 18 & $\mathrm{~L}$ & 0 & 6 & 0 & 0 & 0 & 0 & 6 & 0 & 0 & 3 & 6 & 0 & 0 & 0 \\
\hline 19 & $\mathrm{H}$ & 6 & 0 & 0 & 0 & 0 & 0 & 6 & 0 & 0 & 0 & 0 & 6 & 0 & 0 \\
\hline 20 & $\mathrm{~L}$ & 0 & 6 & 0 & 0 & 1 & 6 & 0 & 0 & 0 & 0 & 0 & 6 & 0 & 0 \\
\hline 21 & $\mathrm{~L}$ & 0 & 5 & 1 & 0 & 0 & 0 & 6 & 0 & 0 & 0 & 0 & 5 & 1 & 0 \\
\hline 22 & $\mathrm{H}$ & 6 & 0 & 0 & 0 & 0 & 0 & 6 & 0 & 0 & 3 & 6 & 0 & 0 & 0 \\
\hline 23 & $\mathrm{H}$ & 6 & 0 & 0 & 0 & 2 & 6 & 0 & 0 & 0 & 3 & 6 & 0 & 0 & 0 \\
\hline 24 & $\mathrm{~L}$ & 0 & 6 & 0 & 0 & 0 & 0 & 6 & 0 & 0 & 3 & 6 & 0 & 0 & 0 \\
\hline 25 & $\mathrm{H}$ & 6 & 0 & 0 & 0 & 1 & 3 & 3 & 0 & 0 & 3 & 6 & 0 & 0 & 0 \\
\hline 26 & $\mathrm{H}$ & 6 & 0 & 0 & 0 & 0 & 0 & 6 & 0 & 0 & 3 & 6 & 0 & 0 & 0 \\
\hline 27 & $\mathrm{~L}$ & 0 & 6 & 0 & 0 & 0 & 1 & 5 & 0 & 0 & 0 & 0 & 5 & 1 & 0 \\
\hline 28 & $\mathrm{~L}$ & 0 & 6 & 0 & 0 & 0 & 0 & 6 & 0 & 0 & 0 & 0 & 6 & 0 & 0 \\
\hline 29 & $\mathrm{H}$ & 6 & 0 & 0 & 0 & 0 & 0 & 6 & 0 & 0 & 3 & 6 & 0 & 0 & 0 \\
\hline 30 & $\mathrm{H}$ & 2 & 0 & 4 & 0 & 2 & 2 & 0 & 4 & 0 & 3 & 2 & 0 & 4 & 0 \\
\hline 31 & $\mathrm{H}$ & 6 & 0 & 0 & 0 & 3 & 5 & 0 & 1 & 0 & 0 & 0 & 6 & 0 & 0 \\
\hline 32 & $\mathrm{H}$ & 4 & 0 & 2 & 0 & 2 & 5 & 0 & 1 & 0 & 2 & 4 & 0 & 2 & 0 \\
\hline 33 & $\mathrm{H}$ & 4 & 2 & 0 & 0 & 0 & 1 & 5 & 0 & 0 & 3 & 6 & 0 & 0 & 0 \\
\hline 34 & $\mathrm{~L}$ & 0 & 6 & 0 & 0 & 1 & 6 & 0 & 0 & 0 & 2 & 6 & 0 & 0 & 0 \\
\hline 35 & $\mathrm{~L}$ & 2 & 4 & 0 & 0 & 0 & 0 & 6 & 0 & 0 & 2 & 6 & 0 & 0 & 0 \\
\hline 36 & $\mathrm{H}$ & 2 & 4 & 0 & 0 & 2 & 6 & 0 & 0 & 0 & 0 & 0 & 6 & 0 & 0 \\
\hline 37 & $\mathrm{H}$ & 6 & 0 & 0 & 0 & 2 & 6 & 0 & 0 & 0 & 0 & 0 & 6 & 0 & 0 \\
\hline 38 & $\mathrm{H}$ & 6 & 0 & 0 & 0 & 0 & 0 & 6 & 0 & 0 & 2 & 6 & 0 & 0 & 0 \\
\hline 39 & $\mathrm{H}$ & 6 & 0 & 0 & 0 & 2 & 6 & 0 & 0 & 0 & 0 & 0 & 6 & 0 & 0 \\
\hline 40 & $\mathrm{H}$ & 6 & 0 & 0 & 0 & 3 & 5 & 0 & 1 & 0 & 0 & 0 & 6 & 0 & 0 \\
\hline 41 & $\mathrm{H}$ & 4 & 2 & 0 & 0 & 2 & 5 & 0 & 1 & 0 & 3 & 6 & 0 & 0 & 0 \\
\hline 42 & $\mathrm{H}$ & 6 & 0 & 0 & 0 & 0 & 0 & 6 & 0 & 0 & 0 & 0 & 6 & 0 & 0 \\
\hline 43 & $\mathrm{~L}$ & 6 & 0 & 0 & 0 & 2 & 6 & 0 & 0 & 0 & 3 & 6 & 0 & 0 & 0 \\
\hline 44 & $\mathrm{~L}$ & 0 & 6 & 0 & 0 & 0 & 0 & 2 & 0 & 4 & 3 & 2 & 0 & 0 & 4 \\
\hline 45 & $\mathrm{~L}$ & 0 & 6 & 0 & 0 & 1 & 5 & 0 & 1 & 0 & 0 & 0 & 6 & 0 & 0 \\
\hline
\end{tabular}

Pos, positive; Neg, negative; H, high; L, low.

cores that contained no tumor were considered mismatches. When considering the validity of findings from a single core for predicting wholesection results, the percentage of matching was simply the proportion of matches among all of the cores. For considering the validity of findings from two or more cores, when the grade of a whole section was positive (or had a high Ki-67 score), the result from the tissue microarray was considered a match if any one of the two or more cores was graded positive. On the other hand, when the grade of a whole section was negative (or had a low Ki-67 score), the result from the tissue microarray was considered a match only if all of the cores were graded negative. The percentage of matching was then calculated as the number of matches divided by the total number of cores analyzed. We assessed the validity of using $1,2,3,4,5$, or 6 cores. The 
correlation between the average stain score of all cores in a particular case and that of the corresponding whole section was measured with the Pearson correlation coefficient, with grade considered a continuous variable. SAS software was used for the statistical analysis (SAS Language Reference, version 8, SAS Institute Inc., Cary, NC, USA, 1999).

\section{Results}

Results are shown in Table 1 . All 45 cases had at least two readable cores (mean, five readable cores per case). Overall, the mean percentage of cores lost in processing was $2.3 \%$ (range, $2-5$ cores per slide), and the mean percentage of cases in which no tumor was present was $4.3 \%$ (range, 1-10 per slide). In all, $6.6 \%$ of the cores were inadequate for staining (Table 2). Averaging over the three markers, the probability that findings from one core would represent those of the whole section was $91 \%$; that of two cores was $96 \%$; and that of three cores was $98 \%$ (Figure 3 ). The addition of a fourth, fifth, or sixth core produced negligible improvement.

Because of the variable amount of tissue in donor blocks, cores could be placed at different depth levels on the recipient tissue microarray block. Therefore, we investigated the number of sections that are needed to obtain more than $90 \%$ of scorable cores from a tissue microarray block. For that purpose, we sectioned one of the two tissue microarray blocks (block 2) and counted the number

Table 2 Summary of microarray cores

\begin{tabular}{|c|c|c|c|c|c|c|}
\hline & \multicolumn{2}{|c|}{ Ki-67 } & \multicolumn{2}{|c|}{ Estrogen receptor } & \multicolumn{2}{|c|}{ p53 } \\
\hline & Block 1 & Block 2 & Block 1 & Block 2 & Block 1 & Block 2 \\
\hline No. of scorable cores & $\begin{array}{c}148 \\
(99 \%)\end{array}$ & $\begin{array}{c}120 \\
(100 \%)\end{array}$ & $\begin{array}{c}146 \\
(97 \%)\end{array}$ & $\begin{array}{c}116 \\
(97 \%)\end{array}$ & $\begin{array}{c}145 \\
(97 \%)\end{array}$ & $\begin{array}{c}116 \\
(97 \%)\end{array}$ \\
\hline Mean & \multicolumn{2}{|c|}{$99 \%$} & \multicolumn{2}{|c|}{$97 \%$} & \multicolumn{2}{|c|}{$97 \%$} \\
\hline No. of cores lost in processing & $\begin{array}{c}2 \\
(1 \%)\end{array}$ & $\underline{0}$ & $\begin{array}{c}4 \\
(3 \%)\end{array}$ & $\begin{array}{c}4 \\
(3 \%)\end{array}$ & $\begin{array}{c}5 \\
(3 \%)\end{array}$ & $\begin{array}{c}4 \\
(3 \%)\end{array}$ \\
\hline Mean & \multicolumn{2}{|c|}{$0.7 \%$} & \multicolumn{2}{|c|}{$3 \%$} & \multicolumn{2}{|c|}{$3 \%$} \\
\hline No. cores without tumor & $\begin{array}{c}5 \\
(3 \%)\end{array}$ & $\begin{array}{c}7 \\
(5 \%)\end{array}$ & $\begin{array}{c}1 \\
(1 \%)\end{array}$ & $\begin{array}{c}10 \\
(8 \%)\end{array}$ & $\begin{array}{c}5 \\
(3 \%)\end{array}$ & $\begin{array}{c}7 \\
(5 \%)\end{array}$ \\
\hline Mean & \multicolumn{2}{|c|}{$4 \%$} & \multicolumn{2}{|c|}{$4 \%$} & \multicolumn{2}{|c|}{$4 \%$} \\
\hline
\end{tabular}

Block 1 contained 150 samples; Block 2 contained 120 samples.

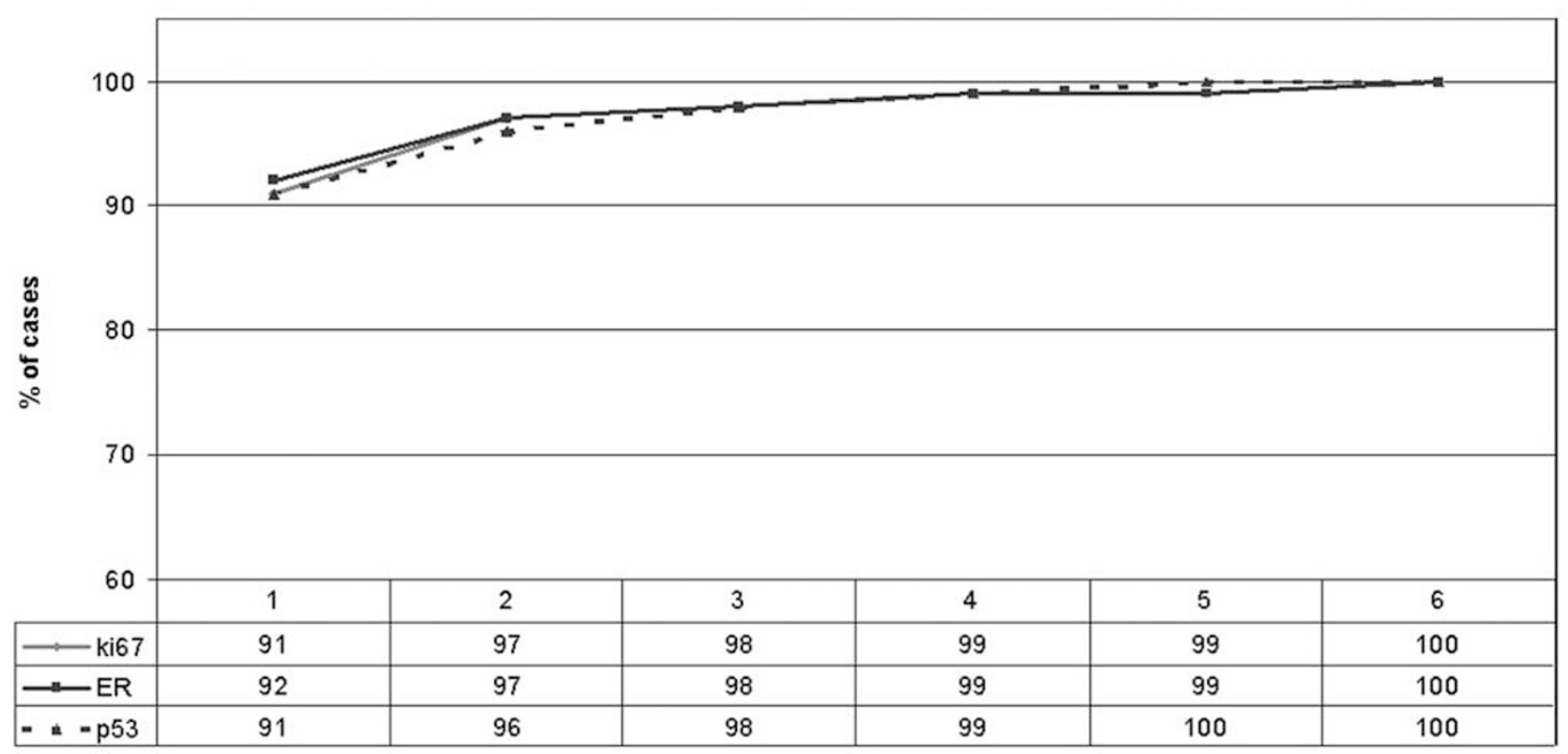

Number of cores

Figure 3 Average probability that 1-6 cores will correctly represent the staining of a whole section. 


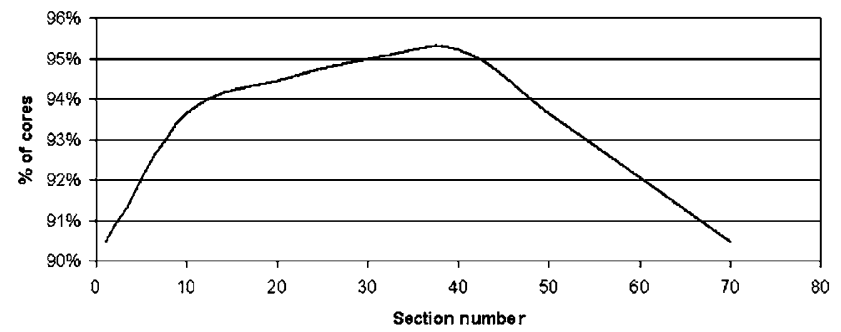

Figure 4 Percentage of usable cores as a function of section number in the tissue microarray.

of cores present in every $10^{\text {th }}$ section (Figure 4 ). Section number 1 was obtained after discarding the first nine sections (facing of the block). Subsequently, more than 70 sections were obtained before the number of cores started to drop.

\section{Ki-67}

According to whole-section analysis, Ki-67 staining was high in 29 cases (64\%); the correlation between the whole-section results and tissue microarray results was high. When high $\mathrm{Ki}-67$ was scored as 1 and low Ki-67 staining as 0 and the value averaged across cores, the Pearson correlation coefficient between whole-section results and tissue microarray results was 0.86. Findings in some cores showed discrepancies with the whole-section results in four cases (cases 33, 35, 36, and 41) (Table 1).

\section{Estrogen Receptor}

The ER was expressed in whole sections in 27 cases $(60 \%)$ and tended to be distributed nonuniformly in nuclei. Findings from tissue microarray agreed well with those from whole sections. In 11 cases, the whole-section grade was 1 (weak-positive) but the tissue microarray cores were, on average, positive; in four of those 11 cases, the cores also showed a nonuniform staining pattern. In one case the whole section was averaged as negative and one core out of six as positive. All of the other negative-staining cases matched in terms of cores vs whole sections. The Pearson correlation coefficient between the average staining across the cores and that of the whole sections was 0.93 .

\section{p53}

Whole-section immunostaining revealed p53 expression in 26 cases (58\%); in those cases, staining tended to be homogeneously distributed throughout the sections. Core results in one case (case 1) were discrepant with whole-section results, but the Pearson correlation coefficient for the average staining among cores vs that of the whole sections was 0.82. None of the cores showed positive expression on a negative whole section.

\section{Discussion}

Tissue microarray technology had its beginnings in 1986 when Battifora introduced the multitumor (sausage) tissue block. ${ }^{6}$ In that method, devised as a control for immunohistochemical staining, large fragments of fresh tissue are processed together as a roll in a less organized fashion than tissue microarray. In 1998, Kononen et al ${ }^{1}$ described the modern tissue microarray. This technique involves making a hole in the recipient tissue microarray block, acquiring a cylindrical core sample from a donor tissue block, and depositing that core into the recipient block. This process is repeated with a precision instrument to array hundreds of tissue specimens.

The tissue microarray technique has been validated for several different tumor types, but not for human ovarian carcinoma. ${ }^{2,7-13}$ Even though a few studies have used tissue microarray to analyze ovarian carcinoma, ${ }^{14,15}$ uncertainty has remained as to whether this technique is useful in such heterogeneous tumors. ${ }^{16,17}$

Most validation studies have found that analysis of three 0.6-mm cores produces higher concordance rates than use of one core and that use of three cores also reduces the problems of higher case loss that is seen with two cores. ${ }^{2,7,18}$ In our study, the addition of a fourth core did not improve concordance. The statistical methods used have also varied from study to study, with some using kappa analysis ${ }^{19}$ and others using regression analysis, ${ }^{20}$ or resampling methods. ${ }^{21}$ We decided to present our findings as 'percentage of cores matching the whole section' ${ }^{2}$ as we believe this to be a simple, easily understood method. According to this method, the chance of correctly representing the whole section with only one core was $91 \%$, that with two cores was $97 \%$, and that with three cores was $98 \%$. Thus, results obtained with whole sections correlated well with those from cores, reaching greater than 95\% representation-the commonly accepted limit of statistical significance-with use of two 1-mm cores.

Previous studies have also used a variety of markers. We selected Ki-67, ER, and p53 as markers because they are used routinely in human ovarian carcinomas; moreover, Ki-67 and ER tend to be distributed heterogeneously and p53 homogeneously in serous carcinomas. ${ }^{22}$ The observation that in four cases (cases 33, 35, 36, and 41) Ki-67, 2 cases (case 33 and 27) ER and one case (case 1) p53 in some of the cores did not match the findings from the whole section reflects the heterogeneity of the tumor across the whole section. ${ }^{23}$ Proportions of immunostain expression for the three markers (Ki67:64\% ER:60\%, p53:58\%) greatly correspond with those described in literature. ${ }^{5,24,25}$ The final score for the whole-section analysis represents an average across different tumor areas; if we were to compare that average with the average findings from all six cores in every case, concordance would reach $100 \%$. 
Thus, regardless of the complexity of the immunohistochemical pattern in the whole section, we found strong correlations between full sections and 1-mm cores in tissue microarrays. If the analysis of a 0.6-mm core (representing 2 or 3 high-power fields) can be considered to quantitatively represent $0.3 \%$ of an entire representative section, then two $1.0-\mathrm{mm}$ cores, as was done in this study, represent approximately $1 \%$ of a representative whole tumor section, covering twice the area of that reported in most of the published validation studies. ${ }^{2}$

The percentage of the missing cores also varies among studies, with reported values ranging from 3 to $17 \% .{ }^{18,20,26}$ The most important factor in minimizing core loss is the technical expertise of the individual constructing the array block and the slides. Using high-quality paraffin to construct the blank (dummy) block, avoiding sudden changes of temperature that will affect the tissue microarray block, and optimizing the size, separation, and depth of the cores can also prevent such losses. By addressing all of these aspects, we were able to obtain $90 \%$ scorable cores on the first acquired section. We found that it was important to calibrate the tissue microarrayer before constructing the block. The donor and recipient needles must be perfectly aligned to prevent gaps from surrounding the cores. Because tissue heterogeneity is a major concern in the use of tissue microarrays, representative areas of the tumor should be selected carefully. Incorrect sampling is still possible, however, and is more likely in infiltrative lesions than in solid tumors. (Only one case in our series [case 30] was an infiltrative lesion.) Overall, $96 \%$ of the cores were correctly sampled. Therefore tumors with an infiltrative pattern might be more accurately assessed with a higher number of cores than would be used for solid tumors.

To assess which sections of the tissue microarray block were most suitable for analysis, we counted the number of cores (regardless of the presence of tumor) in every tenth section. We found that acquisition of 4-mm-deep cores from the donor tissue resulted in more than $90 \%$ of cores being present in 70 sections.

\section{Conclusions}

Despite the variability of antigen expression between cores, analysis of the three markers in a single readable core matched the findings of a whole section more than $90 \%$ of the time. Analysis of two cores raised this representation to more than $96 \%$. Tissue microarray is a powerful and valid technique for analyzing large numbers of human ovarian carcinomas. We conclude that analysis of two 1-mm cores provides sufficient information to achieve results similar to those from whole sections in human ovarian carcinoma; if any result from the two cores remains controversial, use of a third core may be helpful in resolving the discrepancy.

\section{Acknowledgements}

Supported by P01CA64602-1 from the National Cancer Institute, institutional start-up funds, an Institutional Research Grant, and a Career Development Award from the MD Anderson Cancer Center SPORE on Ovarian Cancer to JL.

\section{References}

1 Kononen J, Bubendorf L, Kallioniemi A, et al. Tissue microarrays for high-throughput molecular profiling of tumor specimens. Nat Med 1998;4:844-847.

2 Camp RL, Charette LA, Rimm DL. Validation of tissue microarray technology in breast carcinoma. Lab Invest 2000;80:1943-1949.

3 Benda JA, Zaino R. Histologic classification of tumors of the ovary. In: Benda JA, Zaino R (eds.) Gynecologic Oncology Group Pathology Manual. Buffalo, NY: Gynecologic Oncology Group, 1994.

4 Marx D, Meden H, Brune T, et al. Mib-1 evaluated proliferative activity in ovarian cancer with respect to prognostic significance. Anticancer Res 1997;17: 775-780.

5 Pieretti M, Hopenhayn-Rich C, Khattar NH, et al. Heterogeneity of ovarian cancer: relationships among histological group, stage of disease, tumor markers, patient characteristics, and survival. Cancer Invest 2002;20:11-23.

6 Battifora H. The multitumor (sausage) tissue block: novel method for immunohistochemical antibody testing. Lab Invest 1986;55:244-248.

7 Kallioniemi OP, Wagner U, Kononen J, et al. Tissue microarray technology for high-throughput molecular profiling of cancer. Hum Mol Genet 2001;10:657-662.

8 Mousses S, Bubendorf L, Wagner U, et al. Clinical validation of candidate genes associated with prostate cancer progression in the CWR22 model system using tissue microarrays. Cancer Res 2002;62:1256-1260.

9 Sallinen SL, Sallinen PK, Haapasalo HK, et al. Identification of differentially expressed genes in human gliomas by DNA microarray and tissue chip techniques. Cancer Res 2000;60:6617-6622.

10 Gulmann C, Butler D, Kay E, et al. Biopsy of a biopsy: validation of immunoprofiling in gastric cancer biopsy tissue microarrays. Histopathology 2003;42:70-76.

11 Poremba C, Heine B, Diallo R, et al. Telomerase as a prognostic marker in breast cancer: high-throughput tissue microarray analysis of hTERT and hTR. J Pathol 2002;198:181-189.

12 Rassidakis GZ, Jones D, Thomaides A, et al. Apoptotic rate in peripheral T-cell lymphomas. A study using a tissue microarray with validation on full tissue sections. Am J Clin Pathol 2002;118:328-334.

13 Wang H, Zhang W, Fuller GN. Tissue microarrays: applications in neuropathology research, diagnosis, and education. Brain Pathol 2002;12:95-107.

14 Schraml P, Kononen J, Bubendorf L, et al. Tissue microarrays for gene amplification surveys in many different tumor types. Clin Cancer Res 1999;5:1966-1975.

15 Park SY, Kim HS, Hong EK, et al. Expression of cytokeratins 7 and 20 in primary carcinomas of the stomach and colorectum and their value in the differential diagnosis of metastatic carcinomas to the ovary. Hum Pathol 2002;33:1078-1085. 
16 Horvath L, Henshall S. The application of tissue microarrays to cancer research. Pathology 2001;33: 125-129.

17 Bubendorf L, Nocito A, Moch $\mathrm{H}$, et al. Tissue microarray (TMA) technology: miniaturized pathology archives for high-throughput in situ studies. J Pathol 2001;195:72-79.

18 Fernebro E, Dictor M, Bendahl PO, et al. Evaluation of the tissue microarray technique for immunohistochemical analysis in rectal cancer. Arch Pathol Lab Med 2002;126:702-705.

19 Hoos A, Urist MJ, Stojadinovic A, et al. Validation of tissue microarrays for immunohistochemical profiling of cancer specimens using the example of human fibroblastic tumors. Am J Pathol 2001;158: 1245-1251.

20 Gillett CE, Springall RJ, Barnes DM, et al. Multiple tissue core arrays in histopathology research: a validation study. J Pathol 2000;192:549-553.

21 Rubin MA, Dunn R, Strawderman M, et al. Tissue microarray sampling strategy for prostate cancer biomarker analysis. Am J Surg Pathol 2002;26: 312-319.

22 Koshiyama M, Konishi I, Mandai M, et al. Immunohistochemical analysis of p53 protein and $72 \mathrm{kDa}$ heat shock protein (HSP72) expression in ovarian carcinomas. Correlation with clinicopathology and sex steroid receptor status. Virchows Arch 1995;425:603-609.

23 Nocito A, Kononen J, Kallioniemi OP, et al. Tissue microarrays (TMAs) for high-throughput molecular pathology research. Int J Cancer 2001;94:1-5.

24 Shahin MS, Hughes JH, Sood AK, et al. The prognostic significance of p53 tumor suppressor gene alterations in ovarian carcinoma. Cancer 2000;89:2006-2017.

25 Layfield LJ, Saria EA, Berchuck A, et al. Prognostic value of MIB-1 in advanced ovarian carcinoma as determined using automated immunohistochemistry and quantitative image analysis. J Surg Oncol 1997; 66:230-236 discussion 6-7.

26 Hoos A, Cordon-Cardo C. Tissue microarray profiling of cancer specimens and cell lines: opportunities and limitations. Lab Invest 2001;81:1331-1338. 